\title{
Mixing Enhancement of Wheat Granules in a Hopper Bottom Lab-Scale Mixer Using Discrete Element Simulations
}

Seifeddine Garneoui

PhD student

Szent István University

Faculty of Mechanical Engineering

Hungary

István Keppler

Professor

Szent István University

Faculty of Mechanical Engineering Hungary

Péter Korzenszky

Associate Professor

Szent István University

Faculty of Mechanical Engineering

In the agricultural industry, the conservation of wheat grains in silos after stocking is a hard task. This is because when stocking a large crop, hot aeration from the bottom of the silo is not sufficient to preserve the crop and avoid losses due to the manifestation of moisture between grains and grains-wall. As a concern, engineers, as well as inspectors, challenged day-to-day issues whenever packing such granular material. A screw could be a good solution to improve the dryness of the particles and mix the bed material in case of stocking different types of grains. Mainly, the complexity does emanate from the model used to predict accurately the mixing performance. Emerging generation of simulation codes using the discrete element method (e.g., EDEM ${ }^{\mathbb{R}}$, LIGGGHTS, etc.) have brought an intact solution to the problem of particulate flow and particles inhomogeneity. The present work has sought to develop predictive models for average mixing index and particles velocity distribution assessments in mixing of wheat granules in a small-scaled hopper base screw mixer. A screw-mated-horizontal-ploughs has been utilized to improve the agitation of grains rather than a simple screw. 1, 2 and 4 mated ploughs to the screw axle has been used, also the tilt angle of the 4 mated ploughs case has been varied as follows; $20^{\circ}, 45^{\circ}$ and $70^{\circ}$ then evaluated. Next, findings regarding bed homogeneity are calculated using the Lacey method [1] for quantitative analysis and visual observations have been read out for qualitative assessment. Particles inhomogeneity is at its minimum when more ploughs mated to the screw were used.

Keywords: hopper bottom screw mixer, screw-mated-ploughs, mixing of grains, lacey mixing index, discrete element method.

\section{INTRODUCTION}

Mixing of granular materials is an inevitable process to manufacture various types of products such as pharmaceutical [2], chemical [3], and metallurgical [4]. Agricultural industries face major concern regarding crop preservation from moisture as well as homogeneity prediction whenever blending different grains. After the harvesting of wheat germs, farmers stock the wheat grains in big silos, however maintaining the crop goodness is challenging. Despite the inflow of hot air from the bottom of a silo, the crop may deteriorate because of the moisture content tenacity. To overcome this problem and extend the expiry date of the stock, a rotating screw having horizontal assembled ploughs could be used to stir the grains in all areas of the silo and subsequently allows the air to pass between all grains and dry the whole material bed. Besides, the screw mated ploughs has a great advantage to mix different ingredients in silos until homogeneity state is reached. Additionally, an excess in mixing is unnecessary and leads to more energy consumption,

Received: June 2020, Accepted: August 2020

Correspondence to: Seifeddine Garneoui

Szent István University, Faculty of Mechanical

Engineering, Gödöllo, Pàter Károly u. 1, 2100, Hungary

E-mail: seifeddine.g@gmail

doi:10.5937/fme2004868G

(C) Faculty of Mechanical Engineering, Belgrade. All rights reserved therefore an optimal mixing time is needed to avoid this drawback.

Over the last decade, researchers have tackled the mixing of granular materials in tubes and cylinders [5]. They came out with substantial conclusions using a variety of experimental techniques such as X-ray tracking and positron emission particle tracking (PEPT) to increase the mixing degree of the screw feeder. Results were the followings; by increasing the screw shaft diameter, decreasing the pitch length, increasing the flight diameter, increasing the flight thickness and decreasing the rotational velocity of the screw, the mixing was improved [6]. Others found that the mixing performance could be improved by increasing the pitch length of the screw [7]. The costly experimental work is no more required to find the optimal mixing time and investigate the mixing performance after the emergence of the discrete element method. This method is applied by conducting numerical-based simulations to imitate a real process and obtain detailed pieces of information such as particles velocity and contact forces that cannot be obtained experimentally [8,[9]. Scientists showed by quantitative and qualitative rapprochements that the discrete element method (DEM) is a powerful numerical tool to forecast particles dynamics. This method has been widely used to explore the displacements, velocities, accelerations, etc. of particles inside different types of mixers [9-11]. Discrete element simulation is more 
favourable than other experiments since it could reveal more details of particles flow such as the velocity of every single particle, contact forces between particles and torques. For instance, Boonkanokwong et al, [12] examined the influence of the number of blades in a bladed mixer, they determined that it impacts the velocity of particles and they evidenced that a two or three-blade mixer over one or four-blade mixer is more performing. Chandratilleke et al, [13] used the discrete element method to study the impact of the gap between the impeller and the bottom of the mixer on the mixing performance. They revealed that the forces acting on particles, their velocity field and mixing are interconnected.

In this work, a hopper bottom mixer, one of the shapes of the most common silo, was studied by simulation, and screw having various number of mated horizontal ploughs were set in the hopper base cavity in order to improve the quality, achieve better results of the mixture and minimize revenue losses. The discrete element method (DEM) was applied to investigate the flow of particles inside a lab-scale hopper base screw mixer in which wheat particles were loaded and mixed. This paper focuses on the effect of screw-mated-ploughs on particles mixing performance. The mixing efficiency of the hopper base mixer with different number of ploughs assembled to the screw axle was compared with each other. And finally, the mechanisms of mixing enhancement of binary mixtures in the hopper base mixer by screw-mated-horizontal-ploughs were discussed.

\section{THE DISCRETE ELEMENT METHOD}

The DEM is an effective tool to model the mechanical properties of a bulk material as well as a full process of particles blending instead of the old cost-effective trial and error method. The defined parameters and interactions between particle_particle and particle_wall allow calculating the normal and tangential forces during the mixing process. EDEM ${ }^{\circledR}$ software has been used to investigate the mechanical behaviour of particles motion inside the mixer and evaluate the influence of the assembled ploughs on the mixing effectiveness. The normal and tangential forces, respectively are calculated as follows.

$$
F_{n}=\frac{4}{3} E_{0} \delta^{\frac{3}{2}} \sqrt{R_{0}}-2 \sqrt{\frac{5}{6}} \frac{\ln C_{r}}{\sqrt{\ln ^{2} C_{r}+\pi^{2}}} \sqrt{2 E_{0}} \sqrt[4]{R_{0} \delta} \sqrt{m_{0}} v_{\text {nrel }}
$$

The equivalent young's modulus $E_{0}$ of two intermingling particles is obtained by the ensuing formula. $1 / E_{0}=\left(1-v_{1}^{2}\right) / E_{1}+\left(1-v_{2}^{2}\right) / E_{2} . \delta$ Represents the amount when those two particles overlap and $C_{r}$ is the coefficient of restitution (defined in $\mathrm{EDEM}^{\circledR}$ as the ratio of speed of separation to speed of approach in a collision). The normal overlap $\delta$ characterizes the normal deformation of particles.

$$
F_{t}=-8 G_{0} \sqrt{R_{0} \delta} \delta_{t}-2 \sqrt{\frac{5}{6}} \frac{\ln C_{r}}{\sqrt{\ln ^{2} C_{r}+\pi^{2}}} \sqrt{2 G_{0}} \sqrt[4]{R_{0}} \delta \sqrt{m_{0}} v_{\text {trel }}
$$

The equivalent shear modulus $G_{0}$ of two intermingling particles is obtained by the ensuing formula:
$1 / G_{0}=\left(2-v_{1}\right) / G_{1}+\left(2-v_{2}\right) / G_{2} . \delta_{t}$ Characterizes the tangential overlap between two particles which in turns represents the tangential deformation and $v_{\text {trel }}$ is the tangential constituent of the relative velocity of particles. The tangential overlap is the tangential movement from the first to last contact between two particles, either when one particle begins to roll or slip against another.

A large number of time steps is required to solve the differential equations of the motions of the individual particles resulting from the theorems of linear and angular momentum. However, the setting of time step has a great impact on the simulation results [14]. In our simulations, we have set the time step at $20 \%$ of the Rayleigh time step for all the runs. It has been revealed that the computation time could be decreased by setting a lower value of material young's modulus, however, results may diverge [15]. For instance, previous studies about the mixing of particles in a drum mixer showed that the use of a low young's modulus value will give inaccurate results [16] [17]. Furthermore, researchers investigated the impact of using a lower value of young's modulus on particle dynamics in a bladed mixer. They verified experimentally the simulated results by positron emission particle tracking and they evinced that it impacts the collision between particles [18]. Due to these facts, the young's modulus has not been changed in all the simulations.

\section{DESCRIPTION OF THE NUMERICAL MODEL}

A hopper base screw mixer was studied in this work. The mixer has an upper diameter of $160 \mathrm{~mm}$, a base diameter of $30 \mathrm{~mm}$ and a length of $305 \mathrm{~mm}$, all including $5 \mathrm{~mm}$ wall thickness. A schematic of the conic base mixer is presented in Figure 1 (a), while the side-by-side initial configuration is presented in Figure 1 (b). The screw or screw-mated-ploughs was placed in the middle of the mixer cavity. The different structures of the screw-mated-ploughs are presented in Figures 2 and 3. This mixer design could be used as a silo for stocking granular materials such as wheat, cement, chemical powders, etc. The screw was rotating in the clockwise direction at a given linear rotational velocity. It has two main functions, one is to decrease the moisture content between particles, two, to mix different types of particles and keep the stock homogeneous. The screw has the following dimensions: shaft diameter $=15 \mathrm{~mm}$, screw diameter $=40 \mathrm{~mm}$, screw length $=300 \mathrm{~mm}$, and screw pitch $=20 \mathrm{~mm}$.

Wheat particles were created as a clump of three spheres (Figure 4). The middle sphere has a diameter of $6 \mathrm{~mm}$ and the two other spheres have equal diameters of $5 \mathrm{~mm}$. All the dimensions of the screw mixer and wheat particles remained constant.

The simulation system consists of 11200 particles, corresponding to a $70 \%$ fill fraction by volume. The $70 \%$ value unlike to low filling volume gives an intense flow of particles that makes the mixing more challenging. The simulation started by placing particles separated into the mixer (side-by-side loading) in order to know the performance of the mixer from a totally 
segregated particles state. Particles were loaded under the influence of gravity for 2 seconds time, while the screw/screw-mated-ploughs was static. After particles loading, their velocities were null before setting the screw/screw-mated-ploughs in clockwise rotational motion around its vertical axis with $60 \mathrm{rpm}$ velocity, corresponding to 1 rotation per second. Eight simulations were carried out, the first run using a simple screw, second to the fourth run using 1,2 and 4 ploughs mated horizontally to the screw axle tilted asymmetrically by $70^{\circ}$, fifth to eighth simulations used 4 mated ploughs to the screw having different tilt angles (Figure 3).

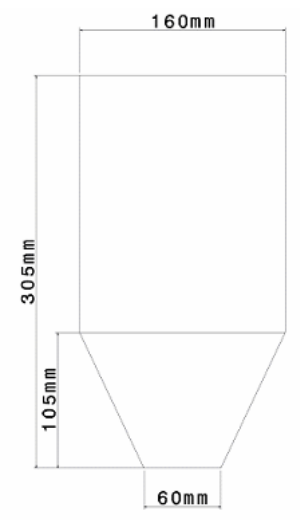

(a)

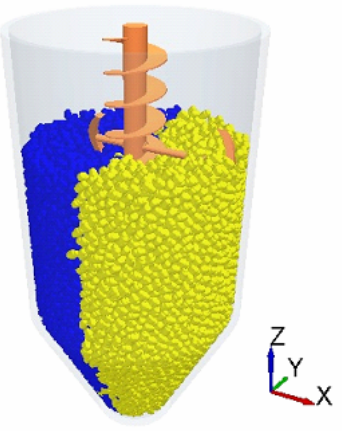

(b)
Figure 1. (a) Schematic of mixer geometry, (b) initial configuration of particles.
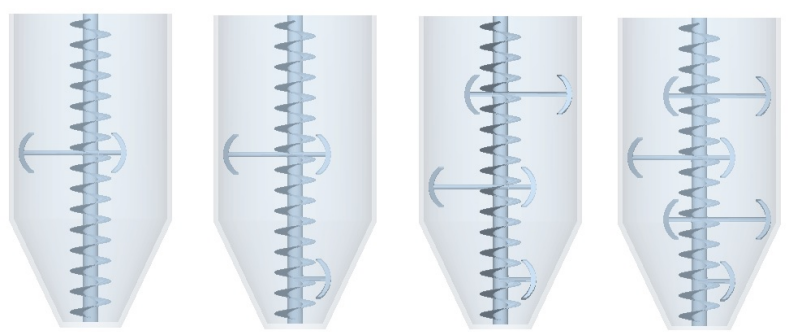

Figure 2. Different number of mated ploughs to the screw used for mixing.

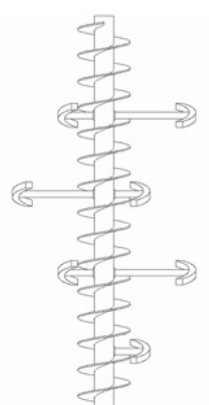

(b)

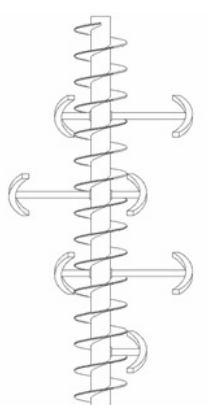

(c)

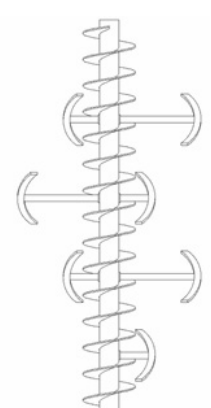

(d)
Figure 3. Geometry of the screw with different tilted ploughs used in the simulations. View from the front, with the screws, rotated in the clockwise direction: a) simple screw, b) screwmated -ploughs asymmetrically oriented by $20^{\circ}$ (c) screwmated-ploughs asymmetrically oriented by $45^{\circ}$ and (d) screw mated ploughs asymmetrically oriented by $70^{\circ}$.
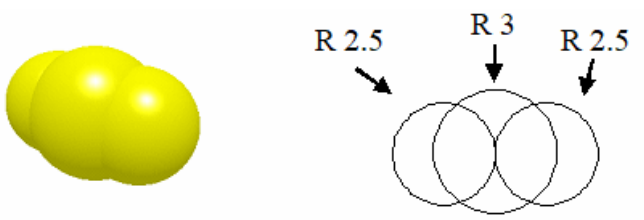

Figure 4. Size and shape of the created wheat particle.
The thickness of these ploughs are $2.5 \mathrm{~mm}$ and they have crescent shapes on both sides and the length from each far side of the plough to the screw axle is unequal, also they are reversely mated along the screw axle (Figure 3). The gap between the lengthier chunk and shorter chunk of the mated horizontal plough and mixer wall are $5 \mathrm{~mm}$ and $20 \mathrm{~mm}$, respectively. Each simulation lasted for 32 seconds, 2 seconds for particles filling and 30 seconds for particles mixing until the material bed becomes almost steady. The micromechanical properties of wheat particles and mixer apparatus were found in literature and used in our simulations (Table 1) [9].

Table 1. Micromechanical parameters of wheat particles and mixer wall.

\begin{tabular}{|l|l|l|}
\hline Parameters & $\begin{array}{l}\text { Particle } \\
\text { (wheat) }\end{array}$ & $\begin{array}{l}\text { Mixer wall } \\
\text { (steel) }\end{array}$ \\
\hline Poison ratio v & 0.4 & 0.3 \\
\hline $\begin{array}{l}\text { Shear modulus } G \\
(\mathrm{~Pa})\end{array}$ & $3,58.10^{9}$ & $8.10^{8}$ \\
\hline Density $\rho\left(\mathrm{kg} / \mathrm{m}^{3}\right)$ & 1460 & 7500 \\
\hline $\begin{array}{l}\text { Coefficient of } \\
\text { restitution } C_{r}\end{array}$ & 0.5 & 0.6 \\
\hline $\begin{array}{l}\text { Coefficient of } \\
\text { friction } \mu_{0}\end{array}$ & 0.3 & 0.25 \\
\hline $\begin{array}{l}\text { Coefficient of } \\
\text { rolling friction } \mu_{r} \\
(\mathrm{~m})\end{array}$ & 0.01 & 0.01 \\
\hline
\end{tabular}

\section{LACEY MIXING INDEX}

This method is established following some statistical analysis, more precisely via the calculation of the variance of particles concentration. The following three equations have to be calculated in order to find the index.

$$
\begin{aligned}
& S^{2}=\frac{1}{N-1} \sum_{i=1}^{n}\left(x_{i}-x_{m}\right) \\
& S_{0}^{2}=x_{m}\left(1-x_{m}\right) \\
& S_{R}^{2}=\frac{x_{m}\left(1-x_{m}\right)}{n}
\end{aligned}
$$

Finally the mixing index is calculated as following:

$$
M=\frac{S^{2}-S_{0}^{2}}{S_{R}^{2}-S_{0}^{2}}
$$

where;

- $S^{2}$ is the variance of the number fraction of white particles in every cell.

- $\quad S_{0}^{2}$ and $S_{R}^{2}$ are defined as the variance of fully unmixed structure and fully mixed structure, respectively.

- $\quad N$ represents the number of cells and $n$ is the average number of particles in each cell

- $x_{m}$ and $x_{i}$ are the average number (concentration) of white particles fraction and the number of white particles fraction in each cell. 
The value of the mixing index ranges between 0 and 1. When it is null means that the material bed is unmixed and when it has a value equals to one then the particles are perfectly mixed. This is a grid-dependent method and more accurate results could be achieved if more cells are considered. The number of cells considered in this work was 64 cells for each simulation (Figure 5).

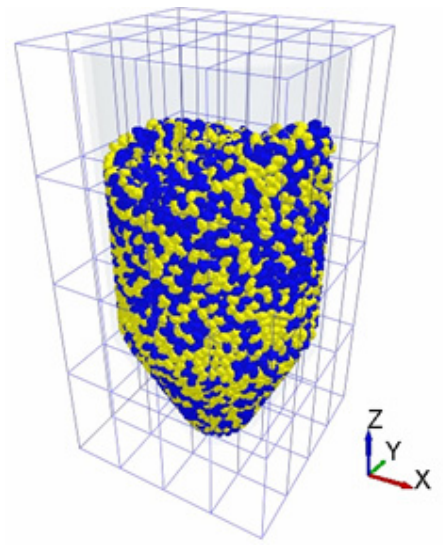

Figure 5. Cells used for Lacey mixing index calculation.

\section{RESULTS AND DISCUSSION}

\subsection{Qualitative analysis}

Clipping function in $\mathrm{EDEM}^{\circledR}$ would let us see the arrangement of the particles from the interior of the material bed. Screenshots were taken each 10 seconds of the mixing time (Figure 6). There were no significant differences between the different screw-mated-ploughs tilt angle configurations, however, the most marked observation to emerge from visual observation was the state between mixed particles with a normal screw and the number of mated ploughs to the screw axle. Figure 6 describes a serie of mixture states when using a normal screw and screw-mated-ploughs.

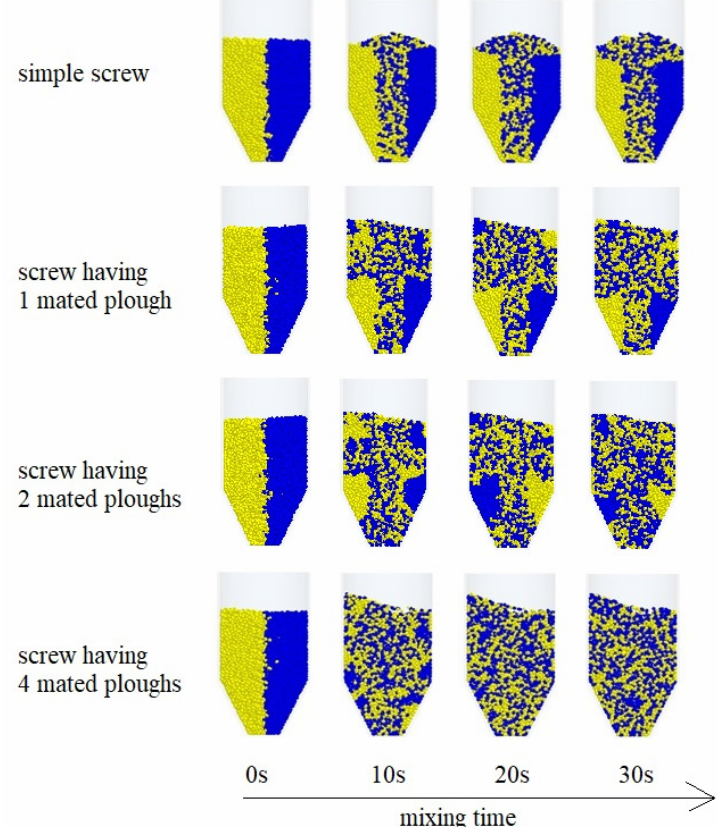

Figure 6. Series of screenshots comparing particles display in the middle of the mixer when using a simple screw and screw having 1,2 and 4 horizontal ploughs, all tilted by $70^{\circ}$ along with simulations.
Some dead regions exist in the mixer wall vicinity when using a normal screw because only particles in the vicinity of the screw were moving vertically up towards the material bed surface. The mated ploughs have drastically improved the mixture by letting particles to move in all the mixer regions. Further analysis of particles velocity has been assessed (Figure 7). It is obvious that 4 mated ploughs to the screw axle has improved the mixture homogeneity.
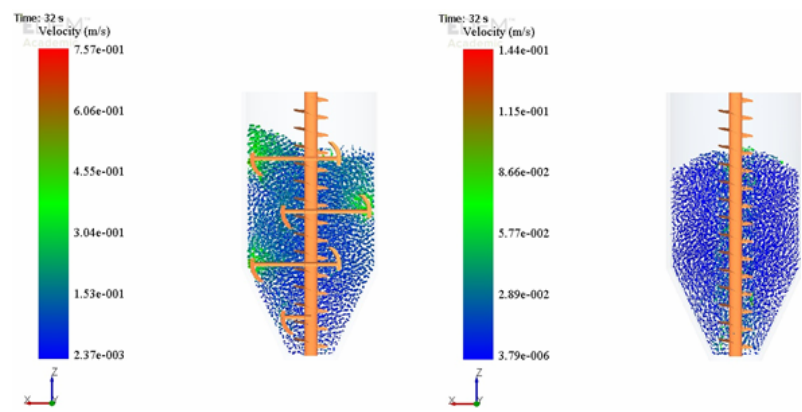

Figure 7. Velocity distribution of particles in case of mixing with a screw-mated-ploughs (4 ploughs) and a normal screw.

The fringes of particles velocity at the end of the process showed that the velocity of particles is much important when using ploughs. This result has further strengthened our confidence in the mated horizontal ploughs to transform the dead zones into active zones, hence improve the whole mixture.

\subsection{Quantitative analysis}

In order to quantitatively describe the mixing degree of the binary mixture, the well-known Lacey index was utilized (section 4). Figure 8 shows the variation of Lacey index over time for different screw-matedploughs configurations and a simple screw and Figure 9 shows the variation of Lacey index over time for a simple screw and screw having different number of mated ploughs to the screw axle. The value of the lacey mixing index was calculated for every rotation in all simulations. The steady-state was reached at 20 s mixing time after which the index varies slightly. The curves reveal that mixing in the hopper bottom mixer with a screw-mated-ploughs is much better than that without mated ploughs, yet mixer using 4 ploughs mated to the screw axle showed relatively high efficiency to mix the particles, however the ploughs tilt angles had no important impact on the mixture.

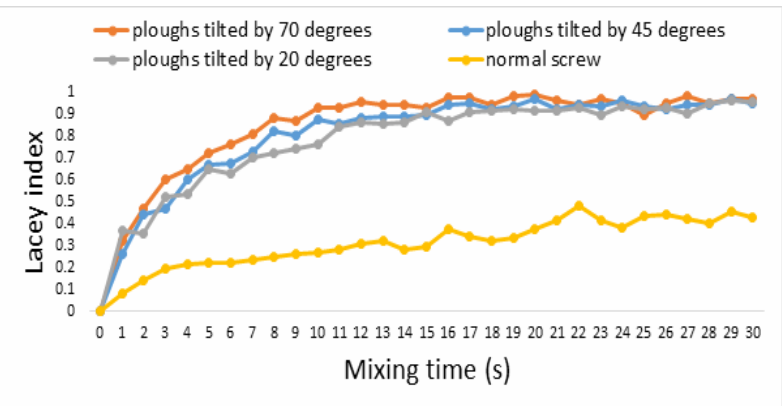

Figure 8. Evolution of mixing degree from an initially completely unmixed state for different tilt angles of the mated ploughs. 


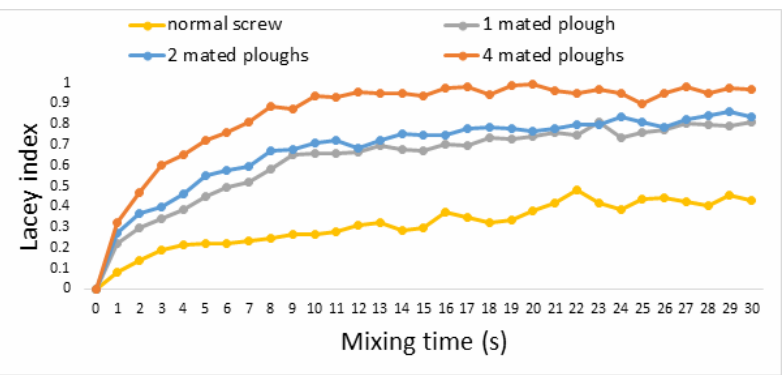

Figure 9. Evolution of mixing degree from an initially completely unmixed state for different number of ploughs mated to the screw axle.

\section{CONCLUSION AND RECOMMENDATIONS}

This two-part study featured qualitative and quantitative assessments of wheat grains mixing. The material was mechanically mixed using a hopper bottom screw mixer under various screw geometric shapes and different orientations of horizontal ploughs assembled to the screw axle. Snapshots were captured across the entire periphery of the screw mixer to show critical characteristics of the mixed materials. It was determined that a screw-mated-ploughs increased the mixing effectiveness. Furthermore, four ploughs mated to the screw axle resulted in improved mixing dynamics compared to other ploughs configurations.

Despite that the qualitative study gives important findings and it does provide an insight into the internal structure of the mixed materials using $\mathrm{EDEM}^{\circledR}$ why certain operating conditions are more favourable than others, there is a quite limitation of this optical visualization method because it does not provide data to justify the noted observations. For instance, when a large number of particles is considered, the ratio of the volume to surface area will increase drastically, however, when using laboratory-scale experiments, then it could be a decent option. Therefore, a quantitative study has been performed in section 5.2 by calculating the index of Lacey.

As for recommendations, further studies could be performed. A coupled DEM/CFD study to examine the flow of air from the bottom to the top of the mixer across the mixture for the different screw configurations.

\section{ACKNOWLEDGMENT}

Financial Support from the Stipendium Hungaricum Scholarship is highly appreciated.

\section{REFERENCES}

[1] W. Godlieb, SA. Gorter, Niels Deen, and Hans Kuipers: DEM and TFM simulations of solids mixing in gas-solid fluidized bed, in: Seventh International Conference on CFD in the Minerals and Process Industries, 9-11.12.2009, Melbourne.

[2] Mauro Cavinatoa, Massimo Bresciani, Marianna Machinb, Guido Bellazzi, Paolo Canua and Andrea C. Santomaso: Formulation design for optimal high-shear wet granulation using on-line torque measurements, International Journal of Pharmaceutics, Vol. 387, pp. 48-55, 2010.
[3] Brenda Remy, Thomas M. Canty, Johannes G. Khinast and Benjamin J. Glasser: Experiments and simulations of cohesionless particles with varying roughness in a bladed mixer: Chemical Engineering Science, vol. 65, No. 16, pp. 4557-4571, 2010.

[4] Ixchel Gijón-Arreortúa and Alberto Tecante: Mixing time and power consumption during blending of cohesive food powders with a horizontal helical double-ribbon impeller: Journal of Food Engineering, vol. 109, pp. 144-152, 2015.

[5] J. R. Metcalf: The mechanics of the Screw Feeder: Proceedings of the Institution of mechanical engineers, vol. 180, No. 1, pp. 131-146, 1965.

[6] Wei-Ren Tsai and Chun-1 Lin: On the mixing of granular material in a screw feeder, Powder Technology, vol. 80, No. 2, pp. 119-126, 1994.

[7] Keisuke Uchida and Koji Okamoto: Measurement technique on the diffusion coefficient of powder flow in a screw feeder by X-ray visualization, Powder Technology, vol. 187, No. 2, pp. 138-145, 2008.

[8] Fenglei Qi, Theodore J. Heindel and Mark Mba Wright: Numerical study of particle mixing in a lab-scale screw mixer using the discrete element method, Powder Technology, vol. 308, pp. 334358, 2017.

[9] Keppler, I., Varga, A., Szabo, I., Katai, L. and Fenyvesi, L: Particle motion around open mixing screws: optimal screw angular velocity, Engineering Computations, vol. 33, No. 3, pp. 896906, 2016.

[10] John Bridgwater: Mixing of powders and granular materials by mechanical means-A perspective, Particuology, vol. 10, No. 4, pp. 397-427, 2012.

[11] Ali Hassanpour, Hongsing Tan, Andrew Bayly, Prasad Gopalkrishnan, Boonho $\mathrm{Ng}$ and Mojtaba Ghadiri: Analysis of particle motion in a paddle mixer using Discrete Element Method (DEM), Powder Technology, vol. 206, No. 1/2, pp. 189194, 2011.

[12] V. Boonkanokwong, B. Remy, Johannes G. Khinast, Benjamin J. Glasser: The effect of the number of impeller blades on granular flow in a bladed mixer, Powder technology, vol. 302, pp. 333-349, 2016.

[13] G.R. Chandratilleke, A.B. Yu, R.L. Stewart and J. Bridgwater: Effects of blade rake angle and gap on particle mixing in a cylindrical mixer, Powder Technology, vol. 193, No. 3, pp. 303-311, 2009.

[14] Xuxin Tu and José E. Andrade: Criteria for static equilibrium in particulate mechanics, International Journal for Numerical Methods in Engineering, vol. 75, pp. 1581-1606, 2008.

[15] Catherine O'Sullivan and Jonathan D. Bray: Selecting a suitable time step for discrete element simulations that use the central difference time integration scheme, Engineering Computations, vol. 21, No. 2/3/4, pp. 278-303, 2004.

[16] Ebrahim Alizadeh, Francois Bertrand and Jamal Chaouki: Comparison of DEM results and 
Lagrangian experimental data for the flow and mixing of granules in a rotating drum, AIChE Journal, vol. 60, No. 1, pp. 60-75, 2013.

[17] H. Chen, Y.G. Xiao, Y.L. Liu and Y.S. Shi: Effect of Young's modulus on DEM results regarding transverse mixing of particles within a rotating drum, Powder Technology, vol. 318, No. , pp. 507517, 2017.

[18] Y.C. Zhou, A.B. Yu, R.L. Stewart, J. Bridgwater: Microdynamic analysis of the particle flow in a cylindrical bladed mixer, Chemical Engineering Science, vol. 59, No. 6, pp. 1343-1364, 2004.

\section{ПОБОЉШАЊЕ МЕШАЊА ЗРНА ПШЕНИЦЕ НА ДНУ ДОЗАТОРА ЛАБОРАТОРИЈСКЕ МЕШАЛИЦЕ ПРИМЕНОМ СИМУЛАЦИЈА МЕТОДОМ ДИСКРЕТНИХ ЕЛЕМЕНАТА}

\section{С. Гарнеуи, И. Кеплер, П. Корзенски}

Чување зрна пшенице у силосима после складиштења представља тежак задатак у пољопривредној индустрији. Разлог томе је што струјање топлог вадуха са дна силоса није довољно да се усев одржи и избегну губици услед појаве влаге између зрна и зидова силоса. Инжењери и инспектори се свакодневно суочавају са овим проблемом приликом паковања зрнастог материјала. Пуж за мешање би могао бити адекватно решење за повећање сувоће зрна и мешање материјала на дну дозатора приликом складиштења различитих врста зрнастих усева. Сложеност проблема не произилази из модела за прецизно предвиђање перформанси мешања. Применом симулације методом дискретних елемената (EDEM, LIGGGHTS, итд.) дошли смо до свеобухватног решења проблема протока и нехомогености честица. Циљ рада је био да се изнађе предикативни модел за просечан индекс мешања и процену дистрибуције брзине честица при мешању зрна пшенице у малом дозатору са пужем за мешање. Мали хоризонтални плугови спојени са пужем доприносили су бољем протресању зрна. Користили смо 1, 2 и 4 плуга спојена са осовином пужа, док је нагибни угао 4 плуга вариран: $20^{0}, 45^{\circ}$ и $70^{\circ}$. Хомогеност материјала на дну дозатора је израчуната применом Лејсијеве методе која се користи за квантитативну анализу и визуелна посматрања. Нехомогеност зрна се своди на минимум када је више плугова спојено са пужем. 